\title{
Effectiveness of Using Natural Materials as a Coagulant for Reduction of Water Turbidity in Water Treatment
}

\author{
Hussein Janna \\ Civil Engineering Department, University of Al-Qadisiyah, Al-Diwaniyah, Iraq \\ Email: Hussein.janna@qu.edu.iq
}

How to cite this paper: Janna, H. (2016) Effectiveness of Using Natural Materials as a Coagulant for Reduction of Water Turbidity in Water Treatment. World Journal of Engineering and Technology, 4, 505-516. http://dx.doi.org/10.4236/wjet.2016.44050

Received: July 5, 2016

Accepted: August 8, 2016

Published: October 14, 2016

Copyright $\odot 2016$ by author and Scientific Research Publishing Inc. This work is licensed under the Creative Commons Attribution International License (CC BY 4.0).

http://creativecommons.org/licenses/by/4.0/

(c) (i) Open Access

\begin{abstract}
Coagulation-Flocculation plays a significant role in drinking water treatment. Laboratory experiments were carried out in order to assess the effectiveness of using Conocarpus Leaves Solution (CLS) as a natural coagulant in conjunction with the synthetic chemical represented by Alum in the water purification. Biological test was carried out to confirm that these leaves are not toxic, followed by optimizing the dosage of alum and then Alum and CLS were applied to the turbid water whose turbidity level has two ranges, $(20$ - 35) NTU and (90 - 120) NTU, using the JAR Test. The parameters determined before and after coagulation were turbidity, $\mathrm{pH}$ and temperature. The experiments showed that the optimum dose of alum coagulant (individually) for high turbid water is about $18 \mathrm{mg} / \mathrm{l}$ with $\mathrm{PH}=7$ and $24 \mathrm{mg} / \mathrm{l} \mathrm{f}$ with $\mathrm{PH}=5$ and 9. In addition, for the low turbidity water, the optimum dose of alum was lower than in the high turbid water. In terms of using Alum in conjunction with CLS, at high range of turbidity, the results show that at $33 \%$ ratio of leaves solution to alum coagulant, there are $50 \%$ and $75 \%$ turbidity reduction performed for the $\mathrm{PH}$ equal to 5 and 9 respectively. Although about $62 \%$ and $65 \%$ turbidity reduction were achieved at $\mathrm{PH}=7$ and $\mathrm{PH}=9$ in the low range level. However, low reduction in turbidity has occurred when the water $\mathrm{PH}=5$. The amount of leaves solution added to the water in the water treatment plant is highly important, hence it decreases the amount of using the synthetic chemicals by about $33 \%$ of the quantity that required for water treatment and that will help both, the water industry and the human health. More studies need to be achieved in particular different concentration of the Conocarpus leaves solution in order to improve the percentage of using the natural material as a coagulant.
\end{abstract}

\section{Keywords}

Water Treatment, Coagulation, Turbidity, Conocarpus, Natural Coagulant 


\section{Introduction}

Water is surely one of the main elements that are involved in the human development considering its influence on human lives. Potable water production from the raw water sources usually involves the use of a coagulation /flocculation stage in order to eliminate turbidity in the form of suspended and colloidal material. Coagulation-Flocculation followed by sedimentation, Filtration and disinfection, often by chlorine, is used worldwide in the water treatment industry before the distribution of treated water to consumers. Coagulation-Flocculation processes play an important role in water treatment by reducing turbidity, organic compounds, bacteria, color, algae, and consequently clay particles for the surface waters.

Although there are new techniques for water and wastewater treatment, however, coagulation/flocculation step is an essential process in the treatment of surface water at which includes removal of turbidity from water, the use of natural coagulants, aiming at a better quality of treated water by reducing the use of chemicals [1].

One of the important aesthetic properties of potable water is turbidity, and it is also a very useful indicator for drinking water quality. Clogging filters or impair disinfection process could occur due to the occurrence of suspended particles, and that leads to increase the risk of waterborne diseases [2].

Many flocculants and coagulants are commonly used in conventional water treatment processes. These materials can be classified into inorganic coagulants such as (aluminum and ferric salts) and synthetic organic polymers (such as polyacrylamide derivatives and polyethyleneimine) and all of these chemicals are very efficient at turbidity removal from water [3].

The high sensitivity of inorganic coagulants to the water $\mathrm{pH}$ and the possibility of secondary contamination of drinking water with traces of toxic synthetic polymeric coagulants or residual iron and aluminum ions are the main challenges of flocculationcoagulation water treatment processes. In addition, many researchers have related Alzheimer's disease to the residual aluminum ions in the treated waters [4]. Moreover, the sludge formed in water treatment plants during flocculation-coagulation with synthetic polymers has a limited potential for recycling because of the non-biodegradability of synthetic polymers [5].

For many centuries in developing countries, natural polyelectrolytes of plant origin have been used for clarifying turbid water [6] [7], such as in India, for 4000 years the Strychnos potatoru was used for water treatment purposes. Moreover, in Egypt and Sudan, almonds soaked bean was used as a coagulant to enhance the water quality in the sixteenth century [8] [9].

Therefore, this study aims to experimentally investigate the effectiveness of using Conocarpus leaves solution (CLS) as an alternative natural material that can be used as a coagulant in order to reduce the quantity of synthetic chemicals.

\section{Material and Method}

The methodology includes firstly the examination of the toxicity of the selected leave. 
In addition to that, the preparation procedure of leaves powder, Alum dose, and turbid water will be also explained in this section.

\subsection{Biological Activity Test}

The materials used to determine whether the leaves are toxic or not are: Agar-agar (from Difco), nutrition Agar (Sigma Aldrich), Petri dish, Paper taper, Conocarpus leaves, and the bacterial samples (Salmonella typhimurium).

The method for testing the leaves to determine whether are toxic or not are include the following steps:

1) Preparation the nutrient Agar and Agar for cultured the bacteria.

2) Inoculation sample of bacteria (Salmonella typhimurium), then spread on the surface of nutrient Agar petri dish by streaking method.

3) Incubation in the incubator at $\left(37^{\circ} \mathrm{C}\right)$ for 24 and 48 hours respectively.

4) Measured toxicity effect of extraction of plants on the growth bacteria (Salmonella typhimurium) and formation inhibition zone for toxicity to the bacteria growth as shown in Figure 1.

\subsection{Preparation of Leaves Solution}

The procedure for preparing the Conocarpus leaves powder includes the following steps: firstly, green leaves (Figure 2) were collected from Conocarpus trees and washed
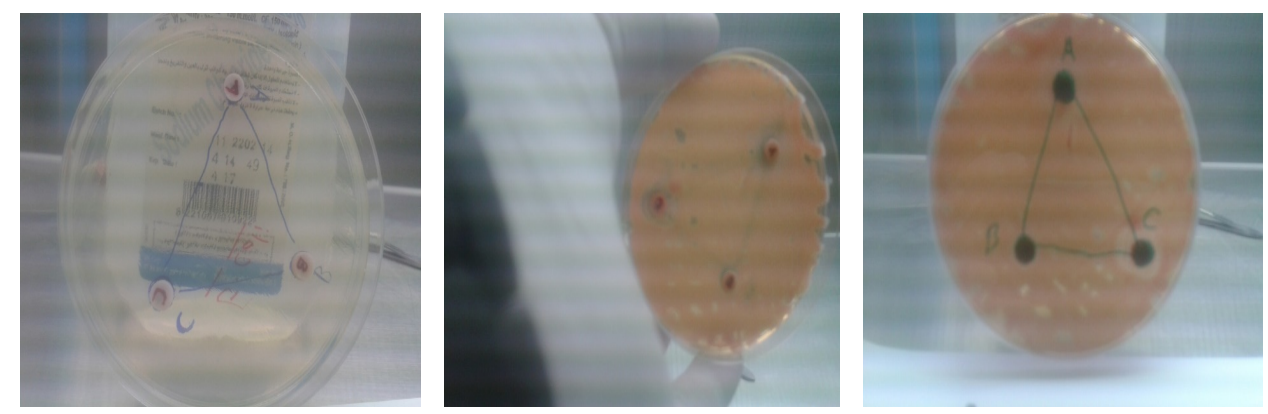

Figure 1. Growth of Salmonella typhimurium on agar-agar for biological toxicity test.
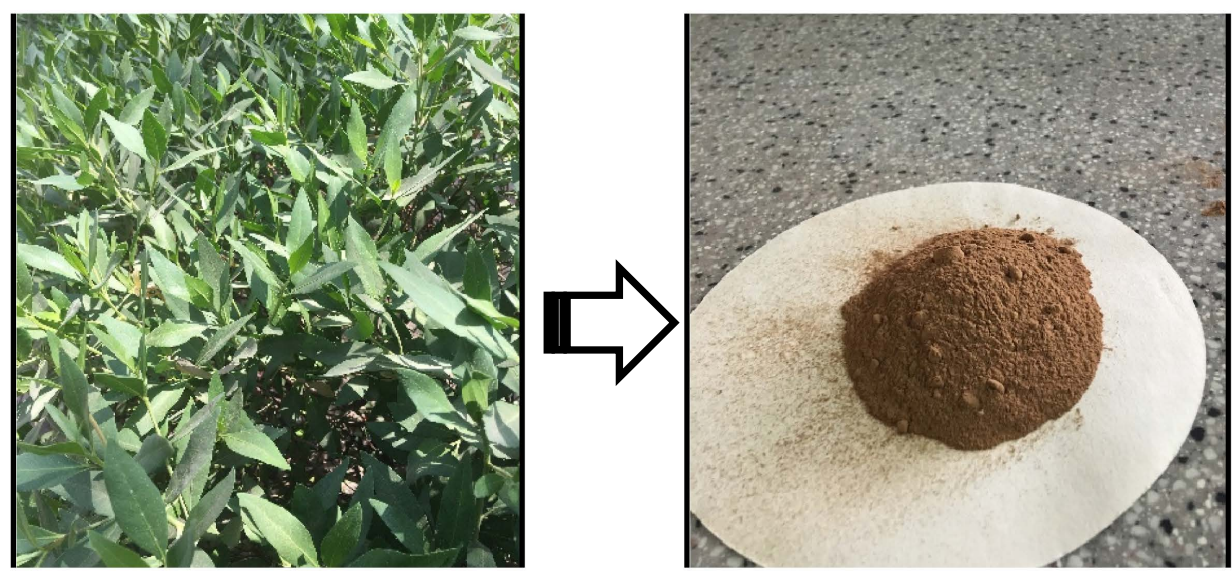

Figure 2. Green and powder Conocarpus leaves as a natural coagulant. 
with firstly, green leaves (Figure 2) were collected from Conocarpus trees and washed with distil water, then left to get dry naturally to a brown colour. The leaves were then ground to fine powder using a kitchen blender, and collect the powder that pass through sieve No.200 as shown in Figure 2. Finally, powder was mixed with water to achieve solubilisation and then filtered with filter paper (Whatman \# 540) so that the filtered solution can be used in combination with Alum solution as a coagulant with a concentration of $10 \mathrm{mg} / \mathrm{l}$.

\subsection{Preparation of Alum}

About $5 \mathrm{~g}$ of alum $\left(\mathrm{Al}_{2}\left(\mathrm{SO}_{4}\right)_{3} \cdot 12 \mathrm{H}_{2} \mathrm{O}\right)$ were added to one litre of water, the solution was mixed at $300 \mathrm{rpm}$ for 1 minute and left for 24 hours in order to have the alum coagulant.

\subsection{Preparation of Turbid Water}

A $30 \mathrm{~g}$ of clay were added to one liter of water and then the suspension mixed at (300 rpm) for 60 minutes to achieve a uniform dispersion of clay particles. In order to complete the hydration of clay materials, it was allowed to the suspension to settle for about 24 hours.

To achieve the desired turbidity just before coagulation, two sets of turbid water were prepared, about $300 \mathrm{ml}$ of the suspension of synthetic turbid water was added to about $(700 \mathrm{ml})$ of water to perform the high turbidity water $(90-120)$ NTU, while only 100 $\mathrm{ml}$ of the suspension of synthetic turbid water was added to about $(900 \mathrm{ml})$ of water to perform the low turbidity water (20 - 35) NTU.

It is important to mention that fresh solutions were prepared daily in order to prevent any ageing effects (like variation in $\mathrm{pH}$, and coagulation activity) and solutions were vigorously shaken before use. It is also important to mention that the initial $\mathrm{PH}$ for the water sample was adjusted with either $(\mathrm{HCL})$ or $(\mathrm{NaOH})$ for the three cases of study of $\mathrm{PH}=5,7$ and 9 before the coagulation.

\subsection{Jar Test Operations}

One of the most commonly used experimental methods for coagulation- flocculation is Jar Test. An ordinary jar test apparatus was used in the experiments to coagulate sample of synthetic turbid water using some coagulants as illustrated in Figure 3, which is consists of six beakers together with six-spindle steel paddles. Samples were mixed homogenously before the jar test starts operating. A range of coagulants concentrations were added in the beakers. The whole procedures in the jar test were conducted in rotating speed since operated initially at $45 \mathrm{rpm}$ for 30 seconds, followed by adding the coagulants dose, then operation the jar test at $125 \mathrm{rpm}$ for 1 minute followed at $40 \mathrm{rpm}$ for 45 minutes. Turbidity was measured initially and at the end of the running Jar test using the turbid meter (Lovibond TB 300 IR). All tests were achieved at an ambient temperature in the range of $25^{\circ} \mathrm{C}-35^{\circ} \mathrm{C}$ and for different turbid ranges (high (90 - 120) NTU, and low (20 - 35) NTU).

\section{Results and Discussion}

After the biological test confirm that Conocarpus leaves are not toxic. Therefore, two 


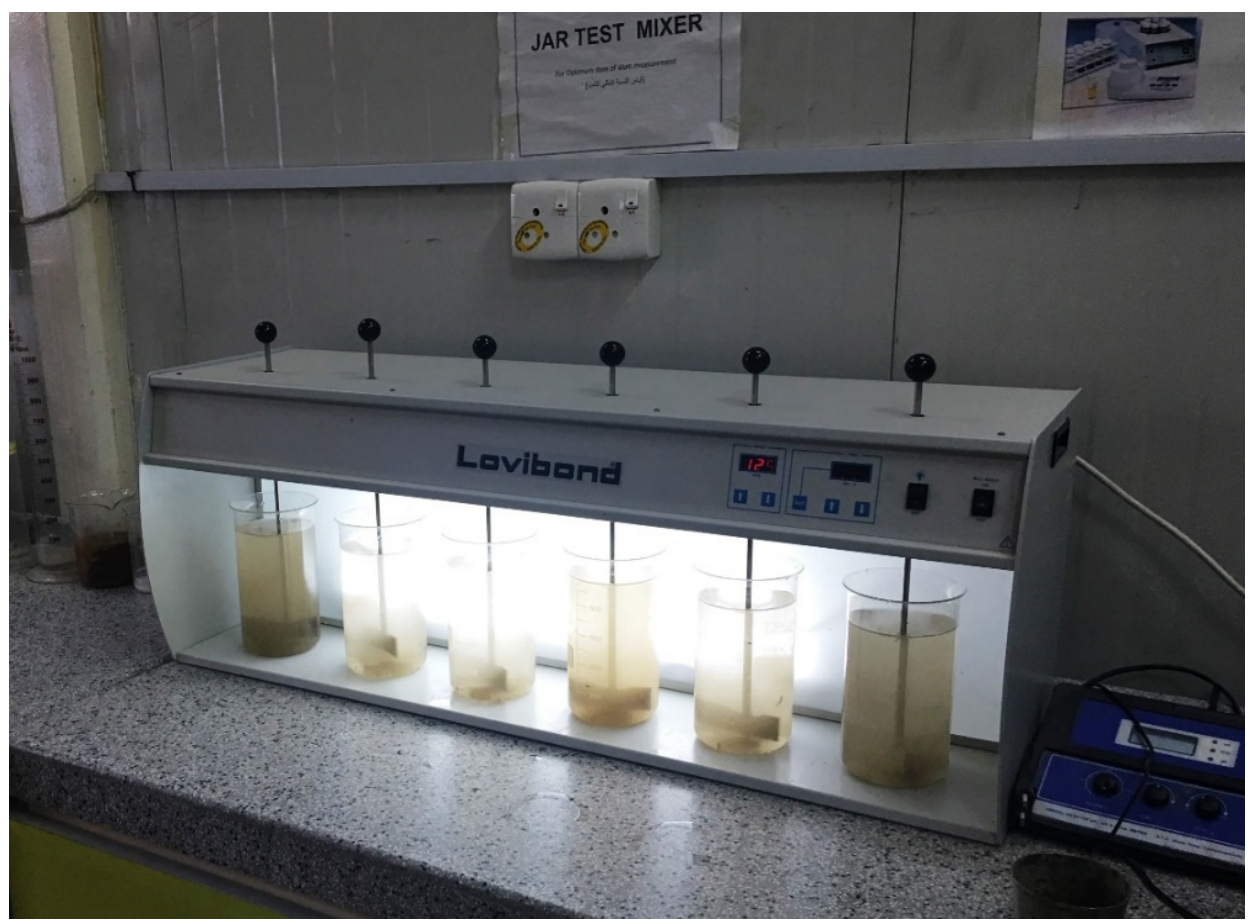

Figure 3. An ordinary jar test apparatus for treatment of turbid water by natural coagulants.

stages of running the jar test were applied, the first one is by determining the optimum dose for the amount of alum coagulant that are required to achieve the best turbidity reduction for the synthetic turbid water, and the second stage represented by mixing the Conocarpus leaves solution (CLS) with the alum (in conjunction) to determine the effectiveness of Conocarpus solution effect of the turbidity removal.

\subsection{Reduction of Turbidity Using Alum Only}

In order to find the optimum dose for the synthetic water, jar test operations using Alum coagulant were carried out twice (sample A and sample B) for the two different turbidity ranges which are they: high $(90$ - 120) NTU and low $(20$ - 35) NTU of synthetic turbid water.

\subsubsection{For High Turbidity Range}

The results of the percentage of the turbidity reduction in the high range level of turbidity $(90$ - 120) NTU are shown in Table 1 . It is apparent from this table that low percentage of reduction could occurred with the $10 \mathrm{mg} / \mathrm{l}$ of Alum,

It can be seen that the reduction of turbidity ranged from $71.3 \%$ to $90.9 \%$ with the dose between $(20$ - 30) $\mathrm{mg} / \mathrm{l}$ for the water that have a $\mathrm{PH}=5$. In addition, between (20 30) $\mathrm{mg} / \mathrm{l}$ of Alum dose performed between $89.2 \%$ to $95.4 \%$ reduction in the turbid water that has a $\mathrm{PH}=9$. For the range of Alum dose $(15-20) \mathrm{mg} / \mathrm{l}$, about $91.6 \%$ to $95.3 \%$, the percentage of reduction had achieved for the water that $\mathrm{PH}=7$. The low percentage of turbidity had happened with $\mathrm{PH}$ of 5 due to fact of increasing residual of Aluminum from coagulant as demonstrated by the study achieved by Yang [10]. 
Table 1. Percentage of turbidity reduction for high turbidity range.

\begin{tabular}{|c|c|c|c|c|c|c|c|}
\hline \multirow{4}{*}{$\mathrm{PH}=5$} & Beaker No. & 1 & 2 & 3 & 4 & 5 & 6 \\
\hline & Alum Conc. (mg/l) & 0 & 10 & 15 & 20 & 30 & 40 \\
\hline & $\%$ of Turbidity reduction (sample A) & - & 40.6 & 68.0 & 90.9 & 89.2 & 65.1 \\
\hline & $\%$ of Turbidity reduction (sample B) & - & 54.4 & 72.3 & 80.0 & 71.3 & 68.3 \\
\hline \multirow{4}{*}{$\mathrm{PH}=7$} & Beaker No. & 1 & 2 & 3 & 4 & 5 & 6 \\
\hline & Alum Conc. (mg/l) & 0 & 10 & 15 & 20 & 30 & 40 \\
\hline & $\%$ of Turbidity reduction (sample A) & - & 93.4 & 94.8 & 95.3 & 94.2 & 94.1 \\
\hline & $\%$ of Turbidity reduction (sample B) & - & 91.2 & 91.6 & 94.3 & 87.6 & 81.3 \\
\hline \multirow{4}{*}{$\mathrm{PH}=9$} & Beaker No. & 1 & 2 & 3 & 4 & 5 & 6 \\
\hline & Alum Conc. (mg/l) & 0 & 10 & 15 & 20 & 30 & 40 \\
\hline & $\%$ of Turbidity reduction (sample A) & - & 91.8 & 93.0 & 93.7 & 95.4 & 91.2 \\
\hline & $\%$ of Turbidity reduction (sample B) & - & 85.3 & 89.0 & 89.2 & 94.9 & 93.8 \\
\hline
\end{tabular}

It appears from Table 1 that the optimum dose which is suitable to perform a good reduction for turbidity for $\mathrm{PH}=5$ and $\mathrm{PH}=9$ is $24 \mathrm{mg} / \mathrm{l}$ for the high range of turbidity. However, the optimum dose for producing a good reduction for the turbidity at $\mathrm{PH}=7$ is $18 \mathrm{mg} / \mathrm{l}$ for the range of turbidity.

\subsubsection{For Low Turbidity Range}

The results of the percentage of the turbidity reduction in the low range level of turbidity (20 - 35) NTU are shown in Table 2. It can be seen that the reduction of turbidity ranged from $87.4 \%$ to $95.9 \%$ with the dose between $(15-20) \mathrm{mg} / \mathrm{l}$ for the water that have a $\mathrm{PH}=5$. With the same range of Alum dose (15 - 20) $\mathrm{mg} / \mathrm{l}$, about $93.5 \%$ to $97.5 \%$, the percentage of reduction had achieved for the water that $\mathrm{PH}=7$. On the other hand, between $(20$ - 30) $\mathrm{mg} / \mathrm{l}$ of Alum dose performed between $92.9 \%$ to $97.5 \%$ reduction in the turbid water that has a $\mathrm{PH}=9$.

As illustrated in Table 2, the optimum dose which is suitable to perform an optimum reduction for turbidity for $\mathrm{PH}=5$ and $\mathrm{PH}=7$ is $18 \mathrm{mg} / \mathrm{l}$ for the low range of turbidity. However, the optimum dose for producing a reduction for the turbidity at $\mathrm{PH}=9$ is 24 $\mathrm{mg} / \mathrm{l}$ for the range of turbidity.

\subsection{Reduction of Turbidity Using Alum and Conocarpus Leaves Solution (CLS)}

\subsubsection{For High Turbidity Range}

The results of the percentage of the turbidity reduction in the high range level of turbidity (90 - 120) NTU using Conocarpus leaves solution and Alum are shown in Table 3.

Figures 4-6 show the general trend of the synthetic water after adding the mixed (solution with the Alum) to reduce the turbidity. From Figures 4-6, it can be seen that all the samples have the same behavior due to their treatment with the alum and 


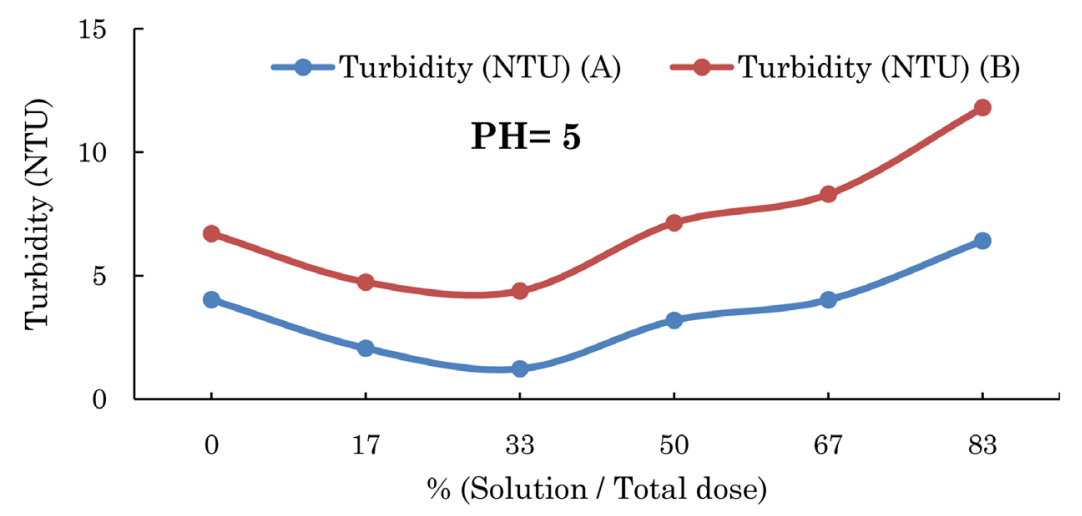

Figure 4. Turbidity reading of high range using alum and Conocarpus leaves solution for with $\mathrm{PH}=5$.

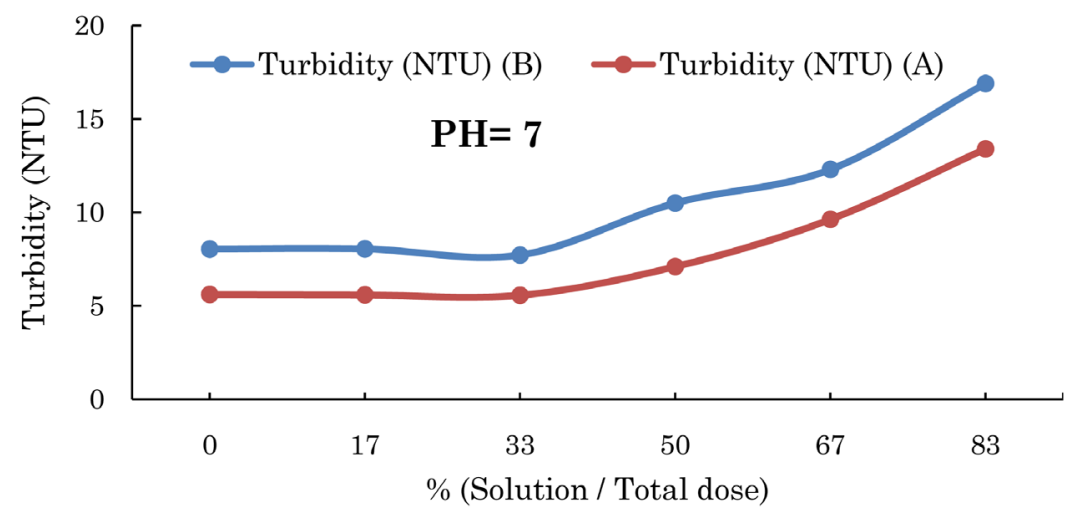

Figure 5. Turbidity reading of high range using alum and Conocarpus leaves solution for with $\mathrm{PH}=7$.

Table 2. Percentage of turbidity reduction for low turbidity range.

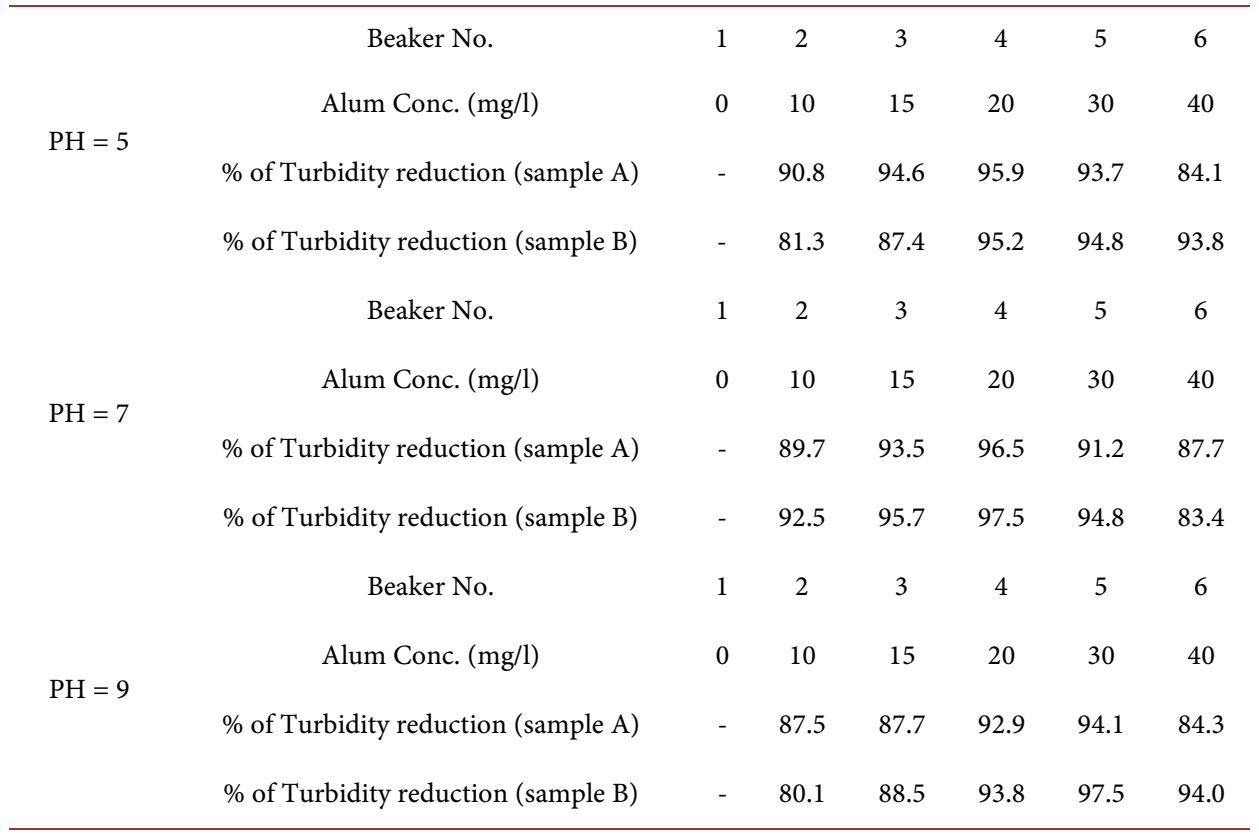




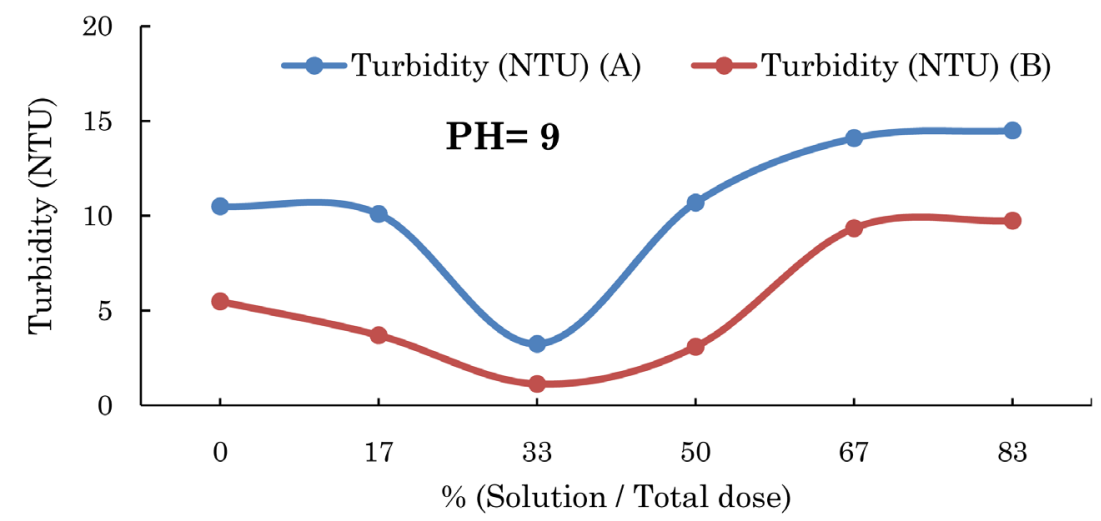

Figure 6. Turbidity reading of high range using alum and Conocarpus leaves solution for with $\mathrm{PH}=9$.

Table 3. Turbidity reduction for high turbidity range using alum and Conocarpus leaves solution.

\begin{tabular}{|c|c|c|c|c|c|c|c|}
\hline \multirow{6}{*}{$\mathrm{PH}=5$} & Beaker No. & 1 & 2 & 3 & 4 & 5 & 6 \\
\hline & Leaves Solution (mg/l) & 0 & 4 & 8 & 12 & 16 & 20 \\
\hline & Alum (mg/l) & 24 & 20 & 16 & 12 & 8 & 4 \\
\hline & \% (Solution/Total dose ) & $0 \%$ & $17 \%$ & $33 \%$ & $50 \%$ & $67 \%$ & $83 \%$ \\
\hline & Turbidity (NTU) (sample A) & 4.03 & 2.06 & 1.23 & 3.19 & 4.02 & 6.41 \\
\hline & Turbidity (NTU) (sample B) & 6.7 & 4.74 & 4.38 & 7.14 & 8.3 & 11.8 \\
\hline \multirow{6}{*}{$\mathrm{PH}=7$} & Beaker No. & 1 & 2 & 3 & 4 & 5 & 6 \\
\hline & Leaves Solution (mg/l) & 0 & 3 & 6 & 9 & 12 & 15 \\
\hline & Alum (mg/l) & 18 & 15 & 12 & 9 & 6 & 3 \\
\hline & \% (Solution/Total dose ) & $0 \%$ & $17 \%$ & $33 \%$ & $50 \%$ & $67 \%$ & $83 \%$ \\
\hline & Turbidity (NTU) (sample A) & 5.61 & 5.59 & 5.57 & 7.1 & 9.63 & 13.4 \\
\hline & Turbidity (NTU) (sample B) & 8.04 & 7.72 & 8.05 & 10.5 & 12.3 & 16.9 \\
\hline \multirow{6}{*}{$\mathrm{PH}=9$} & Beaker No. & 1 & 2 & 3 & 4 & 5 & 6 \\
\hline & Leaves Solution (mg/l) & 0 & 4 & 8 & 12 & 16 & 20 \\
\hline & Alum (mg/l) & 24 & 20 & 16 & 12 & 8 & 4 \\
\hline & \% (Solution/Total dose ) & $0 \%$ & $17 \%$ & $33 \%$ & $50 \%$ & $67 \%$ & $83 \%$ \\
\hline & Turbidity (NTU) (sample A) & 10.5 & 10.1 & 3.25 & 10.7 & 14.1 & 14.5 \\
\hline & Turbidity (NTU) (sample B) & 5.49 & 3.7 & 3.1 & 1.14 & 9.35 & 9.75 \\
\hline
\end{tabular}

leaves solution. It can be seen that about $33 \%$ percentage of mixing the alum with the Conocarpus leaves solution could produce an average reduction of turbidity of about $50 \%$ when $\mathrm{PH}=5$, and around $75 \%$ when $\mathrm{PH}=9$ as shown in Figure 3 and Figure 5. While the reduction that has occurred at $\mathrm{PH}=7$ did not exceed $4 \%$ as shown in Figure 4.

\subsubsection{For Low Turbidity Range}

The results of the turbidity in the low range level of turbidity (20 - 35) NTU using Conocarpus leaves solution and Alum are shown in Table 4. 
Table 4. Turbidity reduction for low turbidity range using alum and Conocarpus leaves solution.

\begin{tabular}{|c|c|c|c|c|c|c|c|}
\hline \multirow{6}{*}{$\mathrm{PH}=5$} & Beaker No. & 1 & 2 & 3 & 4 & 5 & 6 \\
\hline & Leaves Solution (mg/l) & 0 & 3 & 6 & 9 & 12 & 15 \\
\hline & Alum (mg/l) & 18 & 15 & 12 & 9 & 6 & 3 \\
\hline & \% (Solution/Total dose ) & $0 \%$ & $17 \%$ & $33 \%$ & $50 \%$ & $67 \%$ & $83 \%$ \\
\hline & Turbidity (NTU) (sample A) & 1.41 & 0.91 & 1.18 & 1.52 & 1.8 & 2.93 \\
\hline & Turbidity (NTU) (sample B) & 2.42 & 2 & 1.8 & 2.87 & 3.16 & 7.07 \\
\hline \multirow{6}{*}{$\mathrm{PH}=7$} & Beaker No. & 1 & 2 & 3 & 4 & 5 & 6 \\
\hline & Leaves Solution (mg/l) & 0 & 3 & 6 & 9 & 12 & 15 \\
\hline & Alum (mg/l) & 18 & 15 & 12 & 9 & 6 & 3 \\
\hline & \% (Solution/Total dose ) & $0 \%$ & $17 \%$ & $33 \%$ & $50 \%$ & $67 \%$ & $83 \%$ \\
\hline & Turbidity (NTU) (sample A) & 1.34 & 1.12 & 0.36 & 0.74 & 1.81 & 4.61 \\
\hline & Turbidity (NTU) (sample B) & 1.75 & 0.56 & 0.86 & 1.46 & 1.82 & 4.14 \\
\hline \multirow{6}{*}{$\mathrm{PH}=9$} & Beaker No. & 1 & 2 & 3 & 4 & 5 & 6 \\
\hline & Leaves Solution (mg/l) & 0 & 4 & 8 & 12 & 16 & 20 \\
\hline & Alum (mg/l) & 24 & 20 & 16 & 12 & 8 & 4 \\
\hline & \% (Solution/Total dose ) & $0 \%$ & $17 \%$ & $33 \%$ & $50 \%$ & $67 \%$ & $83 \%$ \\
\hline & Turbidity (NTU) (sample A) & 1.33 & 1.09 & 0.5 & 3.09 & 4.01 & 4.17 \\
\hline & Turbidity (NTU) (sample B) & 1.2 & 1.08 & 0.39 & 1.8 & 2.21 & 2.3 \\
\hline
\end{tabular}

It can be seen from Figures 7-9 that although there are initial differences in the turbidity for each sample. However, both samples in each group of $\mathrm{PH}$ have the same trend and behavior. In addition to that, it can be noted that about $33 \%$ percentage of mixing the alum with the Conocarpus leaves solution could produce an average reduction of turbidity of about $62 \%$ when $\mathrm{PH}=7$, and around $65 \%$ when $\mathrm{PH}=9$ as shown in Figure 8 and Figure 9. While the reduction that has occurred at $\mathrm{PH}=5$ did not exceed $21 \%$ as shown in Figure 7.

The organic load in water might be increased by using of natural coagulants, and could increase the microbial activity [11] [12]. Consequently, additional chlorine in the water treatment plant could be consumed by these organic matters and during the disinfection process could act as a precursor of toxic byproducts. Therefore, it would be important to study the behavior of dissolved organic carbon in the treated water to investigate the concentration of DOC with the turbidity removal.

In general, the Conocarpus leaves solution (CLS) has efficiency in removal of turbidity of water, and can reduce the quantity of metal coagulants and that will reflect economically. Although CLS has not proved that can be affected with the temperature. However, there is a possibility of correlation with the that $\mathrm{PH}$ value. Thus, natural sources can generate value-added products, to represent a new source of income. However, with all anticipated benefits especially with water treatment, natural coagulant should be undergoing to tests where certifying its biodegradability, non-toxicity, and viability. 


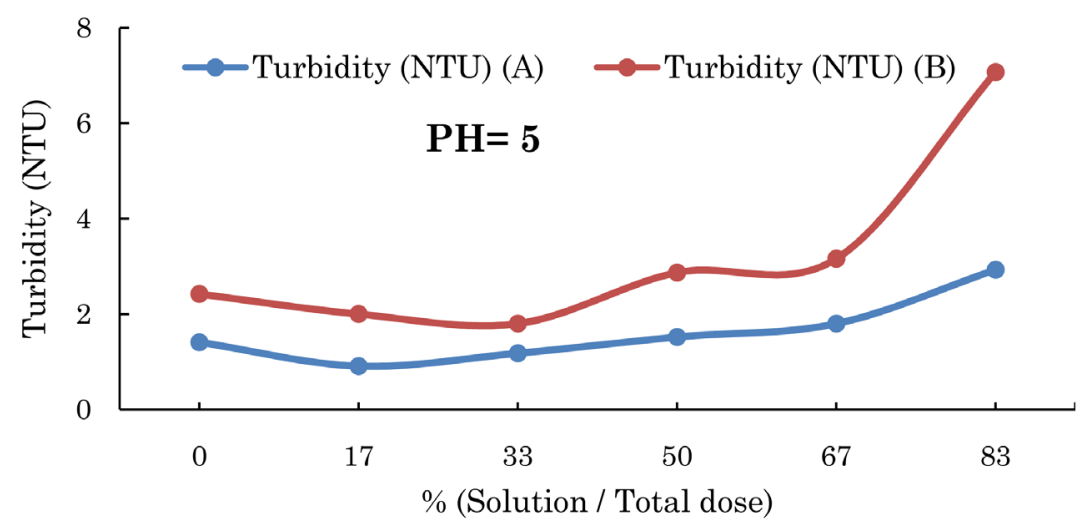

Figure 7. Turbidity reading of low range using alum and Conocarpus leaves solution for with $\mathrm{PH}$ $=5$.

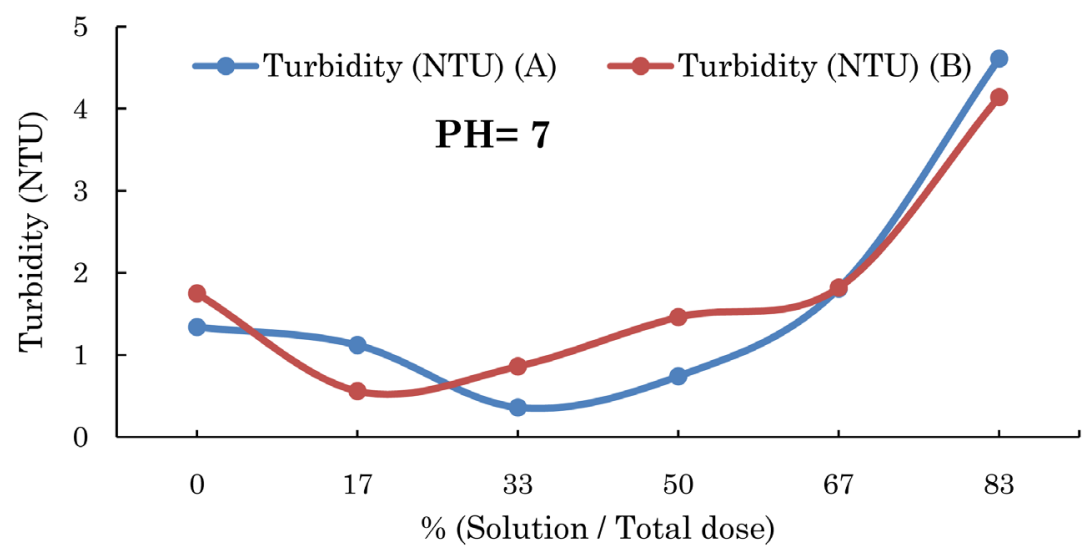

Figure 8. Turbidity reading of low range using alum and Conocarpus leaves solution for with $\mathrm{PH}$ $=7$.

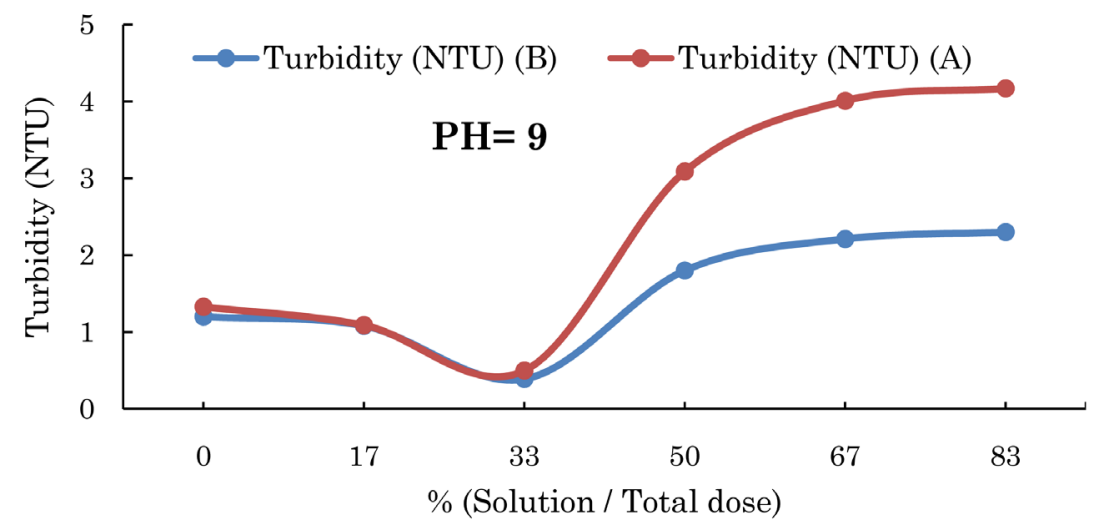

Figure 9. Turbidity reading of low range using alum and Conocarpus leaves solution for with $\mathrm{PH}$ $=9$.

Furthermore, it is important to mention that the turbidity obtained within these percentage of mixing (33\%) of leaves solution with Alum are satisfied with the Iraqi National Standards for drinking water quality. 


\section{Conclusions}

There are different kinds of compounds in the surface water and therefore drinking water should be free from these compounds. Coagulation followed by flocculation is a necessary part of drinking water treatment process. Chemical coagulants are added to water to enhance bonding among particulates to improve the removal particulate, colloidal and dissolved substances. Local natural coagulants are used (Conocarpus Leaves solution) and significant improvement in removing turbidity from synthetic turbid water was found. The results obtained from this study are:

1) It shows that the optimum dose of alum only is about $18 \mathrm{mg} / \mathrm{l}$ and $24 \mathrm{mg} / \mathrm{l}$ for different types of $\mathrm{PH}$.

2) For the low turbidity water, the optimum dose of alum was lower than in the high turbid water.

3) For using alum in conjunction with CLS, at high range of turbidity, the results show that $50 \%$ and $75 \%$ reduction perform when the leaves solution to alum ration is about $33 \%$ for the $\mathrm{PH}$ equal to 5 and 9 respectively.

4) Although about $62 \%$ and $65 \%$ turbidity reduction were achieved at $\mathrm{PH}=7$ and $\mathrm{PH}$ $=9$ in the low range level. However, low reduction in turbidity had occurred when the water $\mathrm{PH}=5$.

5) According to these results, that means there is a providing of about $33 \%$ of the synthetic chemicals that are used as a coagulant and that is more safe for human, environment and economy.

\section{Acknowledgements}

The author would like to thank Engineer(s), Hussein R. Shakir, Abdulla Al-quraishe, and Rasheed Al-hussieny for their efforts in an achieving this work.

\section{References}

[1] Antov, M.G., Šćiban, M.B. and Prodanović, J.M. (2012) Evaluation of the Efficiency of Natural Coagulant Obtained by Ultrafiltration of Common Bean Seed Extract in Water Turbidity Removal. Ecological Engineering, 49, 48-52.

http://dx.doi.org/10.1016/j.ecoleng.2012.08.015

[2] Davis, M.L. and Cornwell, D.A. (2008) Introduction to Environmental Engineering. McGrawHill Companies, New York.

[3] Ramavandi, B. (2014) Treatment of Water Turbidity and Bacteria by Using a Coagulant Extracted from Plantago ovata. Water Resources and Industry, 6, 36-50. http://dx.doi.org/10.1016/j.wri.2014.07.001

[4] Devrimci, H.A., Yuksel, D.A. and Sanin, F.D. (2012) Algal Alginate: A Potential Coagulant for Drinking Water Treatment. Desalination, 299, 16-21. http://dx.doi.org/10.1016/j.desal.2012.05.004

[5] Anastasakis, K., Kalderis, D. and Diamadopoulos, E. (2009) Flocculation Behavior of Mallow and Okra Mucilage in Treating Wastewater. Desalination, 249, 786-791. http://dx.doi.org/10.1016/j.desal.2008.09.013

[6] Schulz, C.R., et al. (1992) Surface Water Treatment for Communities in Developing Coun- 
tries.

[7] Libanius, M. (2008) Fundamentals of Quality and Water Treatment. Atom Ed, Campinas.

[8] Babu, R. and Chaudhuri, M. (2005) Home Water Treatment by Direct Filtration with Natural Coagulant. Journal of Water and Health, 3, 27-30.

[9] Ndabigengesere, A., Narasiah, K.S. and Talbot, B.G. (1995) Active Agents and Mechanism of Coagulation of Turbid Waters Using Moringa-Oleifera. Water Research, 29, 703-710. http://dx.doi.org/10.1016/0043-1354(94)00161-Y

[10] Yang, Z.L., et al. (2010) Effect of pH on the Coagulation Performance of Al-Based Coagulants and Residual Aluminum Speciation during the Treatment of Humic Acid-Kaolin Synthetic Water. Journal of Hazardous Materials, 178, 596-603.

http://dx.doi.org/10.1016/j.jhazmat.2010.01.127

[11] Ndabigengesere, A. and Narasiah, K.S. (1998) Quality of Water Treated by Coagulation Using Moringa oleifera Seeds. Water Research, 32, 781-791. http://dx.doi.org/10.1016/S0043-1354(97)00295-9

[12] Okuda, T., et al. (2001) Isolation and Characterization of Coagulant Extracted from $\mathrm{Mo}$ ringa oleifera Seed by Salt Solution. Water Research, 35, 405-410.

http://dx.doi.org/10.1016/S0043-1354(00)00290-6

Submit or recommend next manuscript to SCIRP and we will provide best service for you:

Accepting pre-submission inquiries through Email, Facebook, LinkedIn, Twitter, etc. A wide selection of journals (inclusive of 9 subjects, more than 200 journals)

Providing 24-hour high-quality service

User-friendly online submission system

Fair and swift peer-review system

Efficient typesetting and proofreading procedure

Display of the result of downloads and visits, as well as the number of cited articles Maximum dissemination of your research work

Submit your manuscript at: http://papersubmission.scirp.org/

Or contactwjet@scirp.org 